\title{
Balneotherapy Research in France
}

\author{
Christian François ROQUES ${ }^{(1-2-3-4)}$ \\ ${ }^{(1)}$ Emeritus Professor of Physical \& Rehabilitation Medicine. \\ Toulouse Paul-Sabatier University. Toulouse (France) \\ ${ }^{(2)}$ AFRETH Scientific Committee President. Paris (France) \\ ${ }^{(3)}$ Dax Institute President. Bordeaux Segalen University. Dax (France) \\ ${ }^{(4)}$ ISMH General Secretary \\ cf.roques@gmail.com
}

Received: $17-10-12$

Acepted: $17-10-12$

\begin{abstract}
In France, several public and/or private scientific investigation bodies are involved in balneotherapy scientific investigation (academic or university-linked institutes in Paris, Nancy, Bordeaux, Grenoble, Clermont-Ferrand, Toulouse; private bodiess in Paris, Aix les Bains, Saujon). However, these last years, the important development in medical balneotherapy investigation could be related to the AFRETH creation. The main data obtained these last years are presented in this paper: main results of the clinical trials and methodological comments.
\end{abstract}

Key words: Balneotherapy Research, Crenotherapy Research, Clinical Trials, France

\section{Investigación Termal en Francia}

\section{Resumen}

En Francia, varias instituciones públicas y/o privadas de investigación científica están involucradas en la investigación científica termal (Universitarias o Institutos vinculados a la Universidad en París, Nancy, Burdeos, Grenoble, Clermont-Ferrand, Toulouse; organismos privados en París, Aix-les-Bains, Saujon). Sin embargo, estos últimos años, el desarrollo importante en la investigación médica termal podría estar relacionado con la creación de la AFRETH. Los principales datos obtenidos en estos últimos años se presentan en este trabajo: principales resultados de los ensayos clínicos y observaciones metodológicas.

Palabras claves: Investigación Termal, Ensayos Clínicos, Francia

REFERENCE STANDARD

Roques CF. Balneotherapy Research in France. Anal Hidrol Med. 2012, Vol. 5, Núm. 2, 161-173. 


\section{ABREVIATIONS}

AFRETH: Association Française pour la Recherche Thermale (French association for balneotherapy research)

ANMCT: Association Nationale des Maires de Commune Thermale (union of balneotherapy resorts' mayors)

CNETH: Conseil National des Etablissements Thzermaux (union of French balneotherapy contractors)

CVI: Chronic Venous Insufficiency

DASH score: Disability Arm Shoulder score

DVT: Deep Venous Thrombosis

ENT: Ear, Nose, Throat

FTCF: Federation Thermale et Climatique Française (French branch of FEMTEC)

GP: General Practitionner.

MCII: Minimum Clinical Important Improvement.

RCT: Randomised Control Trials

\section{INTRODUCTION}

Balneotherapy is based, in France, on three principal aspects: i) the thermal cares delivered to the patients in the balneotherapy care facilities of the hundred French thermal resorts; ii) the development in new trends (prevention, therapeutic education, ageing, rehabilitation); iii) the scientific investigation. Fifty years ago, hydrology was a full branch of medical teaching and all the medical faculties had an hydrology department usually with a laboratory. But the links between universities and resorts were growing less by the 1960s. During these last 15 years, in many countries, scientific investigation renewed on new bases, mainly orientated on a clinical approach. More recently, in France, the creation of the AFRETH provided new scientific and economic opportunities.

\section{BALNEOTHERAPY MEDICINE IN FRANCE}

\section{A medical treatment}

Balneotherapy is, in France, a medical treatment. The cure is prescribed by the patient's physician (GP or specialist) and the resort's doctor prescribes the treatment delivered in the balneotherapy treatment facility. The fees of the resort's doctors (including thermal treatment's prescription, the follow up of the patient during the treatment and correspondence with the family doctor at the end of the treatment) are paid by the patient (about $80 €$ ) and reimbursed by the Social Security $(70 \%)$. The treatments are paid to the balneotherapy care facility (an average of $560 €$ for the compulsory 18 day treatment) and reimbursed by the Social Security $(65 \%)$. Patients suffering work-related accidents or diseases, long duration diseases, 
war-related disabilities are fully reimbursed. The patients on low income, are subsidied for transportation (on the basis of a railway return 2nd class ticket) and for accommodation (maximum $150 €$ ). About $16 \%$ of the patients attending balneotherapy resorts benefit from this allowance. The complementary insurances (mutual or private insurance companies) can complete the reimbursement of the cost to the patients. The average cost to the patients (all expenses included) is $€ 1566$; the total reimbursement ranges from $€ 423$ to 598 according to the benefit of the social allowance and the level of insurance; so the remaining charge to the patients ranges from $€ 598$ to 1143 ; but for the patients fully reimbursed by the social security (work or war related accident or disease, long duration disease) and benefiting from the allowance the average cost for the person is $€ 651$.

\section{An important human and economic issue}

About 100 resorts are functioning in France under the control of health public authorities. In 2011 they treated 520,000 patients (9360,000 days of treatment) and delivered 491,000 well being cares. Most of the patients were female $(65 \%)$ and retired (only $23 \%$ of all the patients were active); $68 \%$ of the patients were 60 years and more old. $17 \%$ of the patients received their first balneotherapy treatment; $38 \%$ of the patients were treated for several conditions; $75 \%$ of the patients were staying in the resort. The prevalence of the different medical orientations showed: rheumatic conditions (66 resorts): 75.3\%; respiratory tract diseases (31 resorts): 9.1\%; vascular conditions (17 resorts): 4.7\%; metabolic conditions (23 resorts): $5.1 \%$; neurological and stress related disorders (8 resorts): $2.7 \%$; dermatological diseases (11 resorts): $2.6 \%$; other conditions ( 25 resorts): $0.1 \%$. NB most of the resorts have an agreement to treat patients for several medical orientations.

The gross product of balneotherapy is $€ 830 \mathrm{M}$; balneotherapy resorts employ 110,000 persons (representing 60,000 full time - direct, indirect and induced - jobs); the global social security financial burden is $€ 231 \mathrm{M}(0.14 \%$ of the health expenses of social security); the financial profit for the collectivity via taxes and social contributions is $€ 190 \mathrm{M}$; which leaves a balance of $€ 59 \mathrm{M}$ (an average of $€ 113$ per patient).

\section{BODIES INVOLVED IN BALNEOLOGICAL SCIENTIFIC INVESTIGATION}

\section{Public research bodies fully dedicated to balneology (Table 1)}

Dax Institute (Bordeaux Segalen University) (Pr Roques, Pr Cambar): this institute is mainly dedicated to bioengineering and training for balneotherapy care providers $^{11-12-13-18}$. 
Table 1 - Bodies involved in balneological scientific investigation

\begin{tabular}{|c|c|c|c|c|c|}
\hline & $\begin{array}{c}\text { No } \\
\text { AFRETH } \\
\text { support }\end{array}$ & $\begin{array}{c}\text { AFRETH } \\
\text { support }\end{array}$ & & $\begin{array}{l}\text { No AFRETH } \\
\text { support }\end{array}$ & $\begin{array}{c}\text { AFRETH } \\
\text { support }\end{array}$ \\
\hline $\begin{array}{l}\text { PARIS } \\
\text { COCHIN }\end{array}$ & $1 \mathrm{RCT}$ & $1 \mathrm{RCT}$ & TOULOUSE & $1 \mathrm{RCT}$ & $\begin{array}{l}1 \text { RCT } \\
1 \text { cohort }\end{array}$ \\
\hline NANCY & $3 \mathrm{RCT}$ & $1 \mathrm{RCT}$ & $\begin{array}{l}\text { BORDEAUX } \\
\text { DAX }\end{array}$ & $1 \mathrm{RCT}$ & $\begin{array}{l}2 \text { cohorts } \\
2 \text { PhD grants }\end{array}$ \\
\hline $\begin{array}{l}\text { MONT- } \\
\text { PELLIER }\end{array}$ & & $1 \mathrm{RCT}$ & $\begin{array}{l}\text { CLERMONT } \\
\text { ROYAT }\end{array}$ & $2 \mathrm{RCT}$ & $2 \mathrm{RCT}$ \\
\hline $\begin{array}{l}\text { AIX les } \\
\text { BAINS }\end{array}$ & $2 \mathrm{RCT}$ & $1 \mathrm{RCT}$ & $\begin{array}{l}\text { GRENOBLE } \\
\text { CIC } \\
\text { LA LECHERE }\end{array}$ & $\begin{array}{l}1 \text { RCT } \\
1 \text { cohort }\end{array}$ & $\begin{array}{l}3 \text { RCT } \\
1 \text { cohort }\end{array}$ \\
\hline SAUJON & & $\begin{array}{c}1 \text { RCT } \\
1 \text { cohort }\end{array}$ & $\begin{array}{l}\text { LYON } \\
\text { CIC }\end{array}$ & & $1 \mathrm{RCT}$ \\
\hline
\end{tabular}

Paris (Faculty of Pharmacy, Dr GP Husson): the Institute of Hydrology of the Paris Faculty of Pharmacy is dedicated to fundamental hydrology scientific research and is not involved in clinical investigation. Dr Husson is the editor of an English speaking non Pubmed listed review: European Journal of Water Quality.

Nancy (laboratoire d'Hydrologie) (clinical investigation) this group has been involved in numerous RCT dedicated to rheumatic conditions ${ }^{4-5-14}$.

La Léchère (Grenoble University): this academic group is fully dedicated to venous diseases. They implemented two RCT on CVI and two programmes of Therapeutic education (one dedicated to CVI another to DVT sequellae ${ }^{3}$ ).

Royat (Clermont-Ferrand University) this group investigates thermal carbotherapy for chronic arterial diseases; they implemented 2 RCT (Raynaud's syndrome, Lower Limb Chronic Arterial Disease ${ }^{7-19}$.

\section{Private research bodies fully dedicated to balneology (Table 1)}

Saujon research group (Dr O. Dubois) this group is fully dedicated to investigation in stress related disorders; with AFRETH funding they published a RCT on General Anxiety Disorder which showed the thermal treatment's superiority to benefit the patients, versus paroxetin, an antidepressant drug ${ }^{6}$. They are implementing a study on an educational programme dedicated to psychotropic drugs withdrawal. 
Aix les Bains research group (Dr A. Françon and Dr R. Forestier) is involved mainly in rheumatic conditions and published several trials. Thermarthrose, implemented with an AFRETH funding, is a conclusive RCT which favours balneotherapy for patients with knee osteoarthritis ${ }^{8-9-10}$.

The AFRETH is a non profit public funding body with an administrative committee and a scientific committee, created in 2004. The AFRETH is dedicated to Actual Medical Benefit and Research \& Development assessment. In the next chapter we shall present more details.

\section{Public research bodies involved in balneology (Table 1)}

Bordeaux University Clinical Pharmacology Laboratory (Actual medical benefit assessment): implemented a feasibility study on metabolic syndrome (Prisme) and an unpublished medico-economic investigation (Escape). Another clinical group provided a RCT on psoriasis ${ }^{15}$.

Clermont-Ferrand Jean-Perrin University Centre (Oncology center) implemented a RCT (Pacthe).

Grenoble University Clinical Investigation Centre (methodological support and operative structure) implemented 2 RCT: Thermarthrose ${ }^{8}$, Thermes\&Veines and an ongoing RCT on post-thrombosis educational stage.

Lyon University Clinical Investigation Centre: they implemented an inconclusive RCT on adult chronic rhinosinusitis.

Montpellier University Clinical investigation Centre is implementing an ongoing RCT on COPD (Chronic Obstructive Pulmonary Disease).

Paris Cochin Hospital PRM Investigation Group (clinical assessment) implemented a RCT on rheumatic conditions ${ }^{16}$ and are implementing a RCT on patients on sickleave with a subacute low back pain.

Toulouse University Gérontopole (geriatrics) implemented a feasibility study on (MAPT) Multimodal Alzheimer Prevention Trial (MAPT) and are working on the role of balneotherapy in geriatrics ${ }^{20}$.

Toulouse Clinical Pharmacology Laboratory (Actual medical benefit assessment): a conclusive RCT on Parkinson's disease ${ }^{2}$ and an inconclusive RCT on child subacute otitis.

Different food or drug companies implemented studies on mineral water drinking, dermocosmetology, ... few of these papers published in the international literature assess balneotherapy actual medical benefit ${ }^{1-21}$. No RCT assessing balneotherapy actual medical benefit supported by these companies was found in the international scientific literature. 


\section{The AFRETH (Association Française pour la Recherche Thermale)}

The Afreth is a non-profit organisation, created in 2004 by the French Union of SPA Contractors (Cneth), the Union of the mayors of spa resorts (ANMCT) and the French branch of the FEMTEC (FTCF). The AFRETH agreed to provide every year a budget of $€ 1.2 \mathrm{M}$ for scientific investigation in balneotherapy. The founders' representatives, who constitute the association's administrative committee, have to take the decision of supporting financially the scientifically validated projects. The scientific validity determined by the scientific committee (12 independent and acknowledged doctors and scientists) on the basis of external independent experts' advice (methodological, clinical and biological scientific experts from French academic institutions). The funding for actual medical benefit assessment is based on contribution of $€ 1 €$ per patient paid by the resorts municipalities and $€ 2$ per patient paid by the contractors. Concerning the new trends' research and development assessment the investigation is paid by the balneotherapy contractors.

Seven calls for projects have been launched and fully implemented. They concerned mainly the actual medical benefit (Table 2). A global budget of $€ 7 \mathrm{M}$ has been agreed.

Table 2 - AFRETH Call for projects results $(2005,2006,2007,2008,2009,2010,2012)$

\begin{tabular}{lccccc}
\hline & $\begin{array}{c}\text { Abstracts } \\
\text { received }\end{array}$ & $\begin{array}{c}\text { Eligible } \\
\text { projects }\end{array}$ & $\begin{array}{c}\text { Full } \\
\text { protocols } \\
\text { received }\end{array}$ & $\begin{array}{c}\text { Scientific } \\
\text { validity }\end{array}$ & $\begin{array}{c}\text { Financial } \\
\text { support }\end{array}$ \\
\hline $\begin{array}{l}\text { Clinical } \\
\text { Assessment }\end{array}$ & 90 & 68 & 66 & 35 & 23 \\
Safety & 4 & 3 & 3 & 3 & 2 \\
Biology & 7 & 3 & 3 & 3 & 1 \\
TOTAL & 101 & 74 & 72 & 41 & 26
\end{tabular}




\section{RESULTS}

Regarding the medical benefit, 2 RCT have been published:

- STOP-TAG (treatment of generalised anxiety): 237 patients have been enrolled to compare balneotherapy versus paroxetin; the main endpoint (anxiety level - Hamilton's scale) significantly improved in the treatment group versus control at 8 weeks and a significantly greater number of patients with $50 \%$ improvement and cured patients were observed in the therapeutic group. Improvement maintained at 6 months for patients who have responded to balneotherapy (effect size: 0.75 ).

- Thermarthrose (knee osteo-arthritis, 462 patients enrolled); the trial compared balneotherapy to usual care (a validated self exercise programme was proposed to both groups). At 6 months, for the main endpoint (Minimum Clinical Important Improvement) significant differences in favour of balneotherapy group versus control were observed. Improvement maintained at 9 months for balneotherapy group (effect sizes were 0.55 for pain and 0.41 for disability).

\section{Publication is in progress for $4 \mathrm{RCT}$}

- Maathermes (overweight and obesity): 257 patients were randomly allocated to balneotherapy or usual care; at 14 months the balneotherapy patients had lost $5.1 \mathrm{~kg}$ versus $0.54 \mathrm{~kg}$ for the control group. $57 \%$ of the balneotherapy group lost at least $5 \%$ of their weight versus $18 \%$ in the control group (effect size 3.8).

- Rotatherm (shoulder cuff tendinitis): 186 patients were allocated between balneotherapy and usual care. At seven months the balneotherapy group showed a significantly better improvement than the control group for pain and function (DASH score). The MCII was achieved by $59 \%$ of the balneotherapy and $18 \%$ of the control groups (effect size: 1.32 - Dash score).

- Treated breast cancer (Pacthe): a RCT comparing the effectiveness of management of women after treatment for breast cancer by a programme including hydrothermal therapy, nutrition education, adapted physical activity to usual care enroled 270 patients. The results showed a significant effect on the primary endpoint (quality of life one year as measured by the SF-36) (effect size: 1.5), and improvement of i) the state of anxiety and depression, ii) the quality of sleep, iii) the weight control, iiii) the consumption of health goods (annual savings of approximately $€ 600$ ).

- Chronic Venous Insufficiency (Therm\&Veines): 425 patients were enrolled and randomised to balneotherapy or usual care. The results demonstrate, for the balneotherapy group, a significant improvement in the 
severity score of chronic venous disease score (Rutherford), pain, quality of life as measured by a specific index of venous disease (CIVIQ) as an index generic (SF36) (effect size: 0.83 - Rutherford score).

- Are in progress RCT i) on COPD (BPCeaux, 337 patients to enrol); ii) on subacute lumbar pain (ITILO, 700 patients to enrol); iii) on post-DVT patients' education (post-thrombosis stage, 240 patients to enrol).

Feasibility studies have been implemented concerning

- The metabolic syndrome: 145 patients were enrolled, 66 were followed for one year. Among these there is a disappearance of the metabolic syndrome in $75 \%$ of them. Among patients with metabolic syndrome disappeared: absence of hypertension was observed in $67 \%$ of patients - previously with hypertension- with no change in medication; fat metabolism returned to normal in $33 \%$ of patients; $75 \%$ of the patients continue the adapted physical activity and $65 \%$ of them still implement dietary recommendations.

- Alzheimer's disease prevention (Multimodal Alzheimer's Prevention trial - MAPT): $35 \%$ of the patients of 70 years and spa guests feel more involved in the programme, $80 \%$ of them considered it acceptable; compliance was then $97 \%$; $90 \%$ were satisfied with having followed; intervention is thus likely to concern 30,000 to 40,000 persons each year in balneotherapy resorts.

- Care to Alzheimer's disease helpers. The respite stay is utilized to help the caregiver (project "Parenthesis"). The intervention is based i) on the hydrothermal treatment and education for carers, ii) a day structure of support for the Alzheimer patients, iii) a suitable home for the couple when it is not possible to accommodate in an ordinary environment, due to the requirements of the Alzheimer patient.

- Therapeutic education of patients with chronic venous insufficiency. Monitoring a cohort of 150 patients was used to evaluate programme outcomes. It was thus possible to measure a satisfaction rate of $75 \%$ among patients and $85 \%$ among physicians. $83 \%$ of patients changed their daily approach to the management of their disease. It was thus possible to determine an improved knowledge of personal care, greater use of the lower limb compression devices, improved quality of life.

Studies are in progress on psychotropic drugs withdrawal and on the geriatric assessment at 70 years.

So research must therefore involve the usual forms of care, but also accompany new trends from their beginning. 
The AFRETH provided also

a) an experts agreement on the methodology of scientific investigation (2006).

b) an unpublished meta-analysis of the existing clinical randomized controlled trials (Pr JP Boissel, cric@t, Laennec School of Medicine, Lyon, France) (2006).

c) Grants for doctoral thesis by students of the Dax Institute 11-12-13-18. $^{\text {. }}$

d) A financial support for a bacteriological investigation of the different types of water ${ }^{17}$.

\section{METHODOLOGICAL ISSUES of the AFRETH managed RCT (Table 3)}

\section{The paradigm of the trial}

The main paradigms used were i) immediate balneotherapy versus delayed balneotherapy (Rotatherm, Thermes\&Veines), ii) Zelen double consent (patients uninformed of the alternative group) paradigm (Maathermes, Thermarthrose), iii) comparison to control group informed of the therapeutic group. Balneotherapy was usually compared to Usual Care except for Stop-Tag (comparison to paroxetin).

\section{Statistical analysis}

The statistical analysis is crucial for the clinical trials which aim to assess the Actual medical benefit. Intention to treat analysis is an essential issue for a conclusive clinical RCT. This analyse could be performed for all the studies except Maathermes; in this last case, a high number of patients shifted to the other therapeutic arm, so ITT analysis was irrelevant; in this particular case, Propensity Score Matching was used to obtain two groups of acceptable comparability. The accuracy of ITT analysis is correlated with an adequate level of acceptance by the patients of the results of the randomisation.

\section{The endpoints}

The choice of the main endpoint is also a crucial issue. Statistically significant differences are necessary but not sufficient; the improvement of the measured endpoint has to be perceived by the patient as a positive change in his clinical condition. So the endpoint has to be relevant to the condition but also to the improvement of the patients. Responder patients (reduction of anxiety $-30 \%$ or $50 \%$ ), Minimum Clinically Important Improvement (MCII in osteo-arthritis of the knee, shoulder rotator cuff tendinitis, loss of $5 \%$ of weight, ...) are essential to give a 
suitable approach to the efficiency of the treatment. In most of the trials such an approach could be implemented.

Table 3 - Data of the different RCT

\begin{tabular}{|c|c|c|c|c|c|c|}
\hline & STOP TAG & $\begin{array}{c}\text { THERM } \\
\text { ARTHROSE }\end{array}$ & MAATHERMES & ROTATHERM & $\begin{array}{c}\text { THERMES\& } \\
\text { VEINES }\end{array}$ & PACTHE \\
\hline $\begin{array}{l}\text { Investigation } \\
\text { Paradigm } \\
\text { Balneo vs }\end{array}$ & Paroxetin & Usual care & Usual care & Usual care & Usual care & Usual care \\
\hline $\begin{array}{l}\text { Enrolment } \\
\text { Paradigm }\end{array}$ & $\begin{array}{c}\text { GP } \\
\text { Psychiatr. }\end{array}$ & $\begin{array}{l}\text { Mass } \\
\text { media }\end{array}$ & GP & $\begin{array}{l}\text { Mass } \\
\text { media }\end{array}$ & $\begin{array}{l}\text { Mass } \\
\text { media }\end{array}$ & Oncologists \\
\hline $\begin{array}{l}\text { Patients } \\
\text { In touch }\end{array}$ & 318 & 630 & 298 & 211 & 3234 & 395 \\
\hline $\begin{array}{l}\text { Patients } \\
\text { randomised }\end{array}$ & 237 & 462 & 257 & 186 & 425 & 251 \\
\hline $\begin{array}{l}\text { Therapeutic } \\
\text { Arm change }\end{array}$ & $3.5 \%$ & $11 \%$ & $42 \%$ & $1 \%$ & $7 \%$ & $0 \%$ \\
\hline $\begin{array}{l}\text { Resorts } \\
\text { involved }\end{array}$ & 4 & 3 & 4 & 4 & 11 & 4 \\
\hline $\begin{array}{l}\text { Statistical } \\
\text { analysis }\end{array}$ & ITT & ITT & $\begin{array}{c}\text { Popensity } \\
\text { Score matching }\end{array}$ & ITT & ITT & ITT \\
\hline $\begin{array}{l}\text { Main } \\
\text { endpoint }\end{array}$ & $\begin{array}{l}\text { Signific. } \\
\text { anxiety }\end{array}$ & $\begin{array}{l}\text { Signific. } \\
\text { Womac }\end{array}$ & $\begin{array}{c}\text { Significant } \\
\text { Weight reduction }\end{array}$ & $\begin{array}{l}\text { Significant } \\
\text { Dash score }\end{array}$ & $\begin{array}{l}\text { Non signif. } \\
\text { Cutan. ulcers }\end{array}$ & $\begin{array}{l}\text { Signif. } \\
\text { QOL }\end{array}$ \\
\hline $\begin{array}{l}\text { Secondary } \\
\text { endpoints }\end{array}$ & $\begin{array}{c}\text { Signif. } \\
\text { Depression } \\
\text { QOL }\end{array}$ & $\begin{array}{l}\text { NS } \\
\text { QOL }\end{array}$ & $\begin{array}{l}5 \% \text { weight loss } \\
\text { Signif. }\end{array}$ & $\begin{array}{l}\text { QOL, health } \\
\text { expenses } \\
\text { Signif. }\end{array}$ & $\begin{array}{c}\text { QOL, pain, } \\
\text { Ruthzerford } \\
\text { Signif }<\text {. }\end{array}$ & $\begin{array}{l}\text { Sleep Weight } \\
\text { control HAD } \\
\text { score Signif }\end{array}$ \\
\hline $\begin{array}{l}\text { Qualitative } \\
\text { endpoint }\end{array}$ & $\begin{array}{c}\text { Reduc. } 30 \% \\
\text { Anxiety } \\
\text { Signif }\end{array}$ & $\begin{array}{l}\text { MCII } \\
\text { Signif. }\end{array}$ & $\begin{array}{l}5 \% \text { weight } \\
\text { Loss } \\
\text { Signif. }\end{array}$ & $\begin{array}{l}\text { MCII } \\
\text { Signif. }\end{array}$ & $\begin{array}{l}\text { Non } \\
\text { relevant }\end{array}$ & $\begin{array}{l}10 \% \text { QOL } \\
\text { improve. } \\
\text { NS }\end{array}$ \\
\hline $\begin{array}{l}\text { Arithmetic } \\
\text { probability }\end{array}$ & x 1.8 & x 1.4 & x 3 & $\times 3$ & $\begin{array}{c}\text { Non } \\
\text { relevant }\end{array}$ & x 1 \\
\hline Effect size & 0.75 & 0.55 (pain) & 3.8 & 1.32 & 0.83 & 1.5 \\
\hline $\begin{array}{l}\text { Medico- } \\
\text { Economic } \\
\text { endpoint }\end{array}$ & NO & $\begin{array}{c}\text { YES } \\
\text { Non signif }\end{array}$ & NO & $\begin{array}{c}\text { Yes } \\
\text { Reduction } \\
\text { NSAID topics } \\
\text { and } \\
\text { physiotherapy. }\end{array}$ & NO & $\begin{array}{c}\text { YES } \\
\text { Reduction } \\
\text { Medical } \\
\text { expenses }\end{array}$ \\
\hline
\end{tabular}

The endpoints concerned mainly the consequences of the disease such as pain, function, QOL; but it could concern also the impairments: overweight, venous ulcers, ... Medico-economic endpoints were often assessed, mainly consumption of health goods.

\section{The patients' enlistment}

The statistical power of a clinical trial is given by the number of patients enrolled in the study and previously calculated according to the main endpoint. Most of the RCT concerning balneotherapy suffer a lack of statistical power as the number of enlisted patients was insufficient. We chose to enrol the number of patients 
previously determined according to the endpoint and we succeeded for six RCT. But we failed to enrol the necessary number of patients in some other studies. The enrolment paradigms were i) the use of the mass media, ii) the intervention of specialists doctors, iii) the intervention of General Practitioners. Concerning the use of mass media very different results were observed: a) Thermarthrose: persons in touch: 630; patients eligible: 462; patients enrolled: 451. b) Thermes\&Veines; persons in touch: 3234; patients eligible: 784; patients enrolled: 425. c) Rotatherm: patients in touch: 245; eligible: 211; enrolled: 186 . The intervention of specialists was relevant for oncologists (Pacthe: persons eligible: 395; patients enrolled: 251) and not suitable for ENT studies ("Ectottit": 170 ENT specialists in touch, 12 active; 24 patients enrolled - number needed: 170) (child subacute otitis) ("Rhinosinusites chroniques de l'adulte": all the ENT specialists members of the French society of ENT in touch; 40 patients enrolled - number needed: 400) (adult chronic rhinosinusitis). Maathermes was based on an enrolment by GP; GP in touch: 7000; accept: 170; active: 71; patients eligible: 298; patients enrolled 257. But GP and psychiatrists succeeded in enrolling 237 patients in Stop-Tag from a population of 318 patients eligible. So we failed to distinguish a golden paradigm for enrolment as the different paradigms produced very different results. However, we observed that the use of specialists i) to enroll patients, ii) to assess patients, iii) the lack of awareness of the spa treatment for the condition were barriers to recruitment. Recruitment by the mass media, rapid access to an investigator to assess the eligibility of the patient, the high prevalence of the disease, the awareness of thermal treatment for this disease favored the recruitment of patients.

\section{CONCLUSION}

From our experience, we have to emphasize the difficulties related to RCT implementation as no paradigm for assessment and enlistment can be identified. The need of new methodological designs, alternative to usual RCT to investigate such a complex therapeutic intervention is obvious. France has engaged a significant endeavour in the field of balneotherapy investigation, but now a large and international cooperation in balneology investigation and balneotherapy assessment would be necessary.

\section{REFERENCES}

1. Bodemer C, Bourrat E, Mazereeuw-Hautier J, Boralevi F, Barbarot S, Bessis $\mathrm{D}$, et al. Short- and medium-term efficacy of specific hydrotherapy in inherited ichthyosis. Br J Dermatol. 2011 Nov;165(5):1087-94. 
2. Brefel-Courbon C, Desboeuf K, Thalamas C, Galitzky M, Senard JM, Rascol $\mathrm{O}$, et al. Clinical and economic analysis of spa therapy in Parkinson's disease. Mov Disord. 2003 May;18(5):578-84

3. Carpentier PH, Satger B. Randomized trial of balneotherapy associated with patient education in patients with advanced chronic venous insufficiency. $\mathrm{J}$ Vasc Surg. 2009 Jan;49(1):163-70.

4. Constant F, Collin JF, Guillemin F, Boulangé M. Effectiveness of spa therapy in chronic low back pain: a randomized clinical trial. J Rheumatol. 1995 Jul;22(7):1315-20.

5. Constant F, Guillemin F, Collin JF, Boulangé. Use of spa therapy to improve the quality of life of chronic low back pain patients. M. Med Care. 1998 Sep;36(9):1309-14.

6. Dubois O, Salamon R, Germain C, Poirier MF, Vaugeois C, Banwarth B, et al. Balneotherapy versus paroxetine in the treatment of generalized anxiety disorder. Complement Ther Med. 2010 Feb;18(1):1-7.

7. Fabry R, Monnet P, Schmidt J, Lusson JR, Carpentier PH, Baguet JC, et al. Clinical and microcirculatory effects of transcutaneous CO2 therapy in intermittent claudication. Randomized double-blind clinical trial with a parallel design. Vasa. 2009 Aug;38(3):213-24.

8. Forestier R, Desfour H, Tessier JM, Françon A, Foote AM, Genty C, et al. Spa therapy in the treatment of knee osteoarthritis: a large randomised multicentre trial. Ann Rheum Dis. 2010 Apr;69(4):660-5.

9. Forestier R, Françon A, Saint Arroman F, Bertolino C, Graber-Duvernay B, Guillemot A, et al. Are SPA therapy and pulsed electromagnetic field therapy effective for chronic neck pain? Randomised clinical trial. Second part: medicoeconomic approach. Ann Readapt Med Phys. 2007 Apr;50(3):148-53.

10. Forestier R, Françon A, Saint-Arromand F, Bertolino C, Guillemot A, GraberDuvernay B, et al. Are SPA therapy and pulsed electromagnetic field therapy effective for chronic neck pain? Randomised clinical trial First part: clinical evaluation. Ann Readapt Med Phys. 2007 Apr;50(3):140-7.

11. Grégoire P, Fardeau ML, Guasco S, Lagière J, Cambar J, Michotey V, et al. Desulfosoma profundi sp. nov., a thermophilic sulfate-reducing bacterium isolated from a deep terrestrial geothermal spring in France. Antonie Van Leeuwenhoek. 2012 Mar;101(3):595-602.

12. Grégoire P, Fardeau ML, Joseph M, Guasco S, Hamaide F, Biasutti S, et al. Isolation and characterization of Thermanaerothrix daxensis gen. nov., sp. nov., a thermophilic anaerobic bacterium pertaining to the phylum "Chloroflexi", isolated from a deep hot aquifer in the Aquitaine Basin. Syst Appl Microbiol. 2011 Nov;34(7):494-7.

13. Grégoire P, Bohli M, Cayol JL, Joseph M, Guasco S, Dubourg K, et al. Caldilinea tarbellica sp. nov., a filamentous, thermophilic, anaerobic bacte- 
rium isolated from a deep hot aquifer in the Aquitaine Basin. Int J Syst Evol Microbiol. 2011 Jun;61(Pt 6):1436-41.

14. Guillemin F, Constant F, Collin JF, Boulange M. Short and long-term effect of spa therapy in chronic low back pain. Br J Rheumatol. 1994 Feb;33(2):148-51.

15. Léauté-Labrèze $C$, Saillour $F$, Chêne $G$, Cazenave $C$, Luxey-Bellocq ML, Sanciaume C, et al. Saline spa water or combined water and UV-B for psoriasis vs conventional UV-B: lessons from the Salies de Béarn randomized study. Arch Dermatol. 2001 Aug;137(8):1035-9.

16. Nguyen M, Revel M, Dougados M. Prolonged effects of 3 week therapy in a spa resort on lumbar spine, knee and hip osteoarthritis: follow-up after 6 months. A randomized controlled trial.. Br J Rheumatol. 1997 Jan;36(1):77-81.

17. Pagnier I, Raoult D, La Scola B. Isolation and identification of amoebaresisting bacteria from water in human environment by using an Acanthamoeba polyphaga co-culture procedure. Environ Microbiol. 2008 May;10(5):1135-44.

18. Pécastaings S, Bergé M, Dubourg KM, Roques C. Sessile Legionella pneumophila is able to grow on surfaces and generate structured monospecies biofilms. Biofouling. 2010 Oct;26(7):809-19.

19. Schmidt J, Monnet P, Normand B, Fabry R. Microcirculatory and clinical effects of serial percutaneous application of carbon dioxide in primary and secondary Raynaud's phenomenon. Vasa. 2005 May;34(2):93-100.

20. Secher M, Soto M, Gillette S, Andrieu S, Villars H, Vellas B, et al. Balneotherapy, prevention of cognitive decline and care the Alzheimer patient and his family: outcome of a multidisciplinary workgroup. J Nutr Health Aging. 2009 Nov; 13(9):797-806.

21. Taieb C, Sibaud V, Merial-Kieny C. Impact of Avène hydrotherapy on the quality of life of atopic and psoriatic patients. J Eur Acad Dermatol Venereol. 2011 Feb;25 Suppl 1:24-9. 